\title{
B. F. Skinner \\ (20 March 1904-18 August 1990)
}

\section{An Appreciation by Chris Cullen and Carol Cole}

\section{Chris Cullen writes:}

Emyr rang through from the switchboard. "It's a call from the United States, Chris, someone called Fred Skinner." I thought it must be a practical joke but it turned out to be B. F. Skinner responding to a letter I had written a few weeks before. I had met his daughter, Deborah, and she had said that he would be delighted to meet with British behaviourists - why didn't I ask to see him next time he came to the UK? So I did and here he was telephoning to suggest that we might have tea with him in London. On a wet and windy day in October 1976 John Hattersley, Lawrence Tennant and I drove to the Russell Hotel. We talked about behaviour modification, cognitive psychology (cognitive science hadn't been invented then), private events, verbal behaviour and designing a better world. He was quiet, amusing, diffident and generous. He must have had better things to do with his time.

Burrhus Frederic Skinner (Burrhus was his mother's maiden name and was always troublesome - he rarely used it) was born in Susquehanna, a small town in Pennsylvania. He lived in the house in which he was born until he went to Hamilton College where he majored in English Literature and afterwards embarked upon a career as a writer. Robert Frost encouraged him. In a letter of 7 April 1926 he told the young Skinner that ". . y you have the touch of art. The work is clean run. You are worth twice anyone else I have seen in prose this year." However, Skinner felt that he was not making an original contribution, and thought that he was imitating the work of people such as Katherine Mansefield and Maupassant. He gave up writing in what he called the "Dark Year" and eventually decided that he had failed as a writer because he had nothing important to say. Although he never lost his interest in art and literature, he moved into science via Proust, Loeb, Pavlov and Bertrand Russell. Fred Keller, who was a graduate student at Harvard, had a particularly strong influence on the young Skinner, brilliantly and amusingly described by them both at the 1989 ABA convention dinner to mark Keller's 90th birthday.

There will be many formal and comprehensive analyses of his work; these brief appreciations are not the place to rehearse those aspects of his life. He published over twenty books and countless papers; he received honorary degrees, awards and prizes from many prestigious institutions. He was the twentieth century's most notable psychologist, although he always doubted that he should consider himself to be a psy'che-ologist since he was primarily interested in the study of behaviour. His legacy is enormous and as significant as that of Darwin, Marx, Einstein and Freud.

One of his early influences, which stayed with him throughout his life, was the 
work of Francis Bacon, and Baconian principles characterized his professional work. He studied nature, not books, which led him to be generally ignorant of the work of other psychologists. Instead he built instruments and gadgets with which to control behaviour. Although the vast majority of his writing was about human behaviour he never lost his interest in demonstrating behaviour principles with nonhumans. With Robert Epstein and some graduate students he designed contingencies to teach "insight", "symbolic communication" and "self-awareness" to pigeons, work which, even though somewhat tongue-in-cheek, was published in Science and Nature. Epstein described Skinner's enthusiasm for control: "He improvised a clever gadget from an old chocolate tin, two spools of thread, and a slice of an adding machine cover, among other things. The tin was turned slowly by a motor, and after the basic pieces were in place, he insisted that we plug it in. I objected. 'It's not finished. Why plug it in?' He paused, his face brightened, and he replied, 'Why, to see it go of course!?",

A second Baconian principle had a very powerful role in his life: nature to be commanded must be obeyed. He never doubted that his own behaviour was a function of contingencies of reinforcement and of evolution and this led him to assign his own achievements to genetic and environmental histories rather than to creativity, intelligence or insight. In concluding a lecture at the Poetry Centre in New York City in 1971, on analysing the behaviour of producing a poem, he said "And now my labour is over. I have had my lecture. I have no sense of fatherhood. If my genetic and personal histories had been different, I should have come into possession of a different lecture. If I deserve any credit at all, it is simply for having served as a place in which certain processes could take place. I shall interpret your polite applause in that light."

Most of his work was concerned with the role of a science of behaviour in the design of a better world. He was impressed by the work of E. F. Schumacher and his own utopian novel Walden Two, was an early attempt to show how small communities could live more peacefully and productively, with a minimum of wasteful consumption and pollution. Some have attempted to organize themselves along the lines suggested by Skinner, the most notable being Twin Oaks and Comunidad Los Horcones in Mexico. Unfortunately, it is clear that we are still some considerable way from using behavioural science to deal with the terrifying problems of over-population, pollution, famine, threat of war and inequality which were his major concerns.

He was humorous and self-mocking. Shortly before meeting Robert Epstein, who later went on to edit many of his notes, he spoke with his assistant, MJ. "You have a rival-a very nice young man. He wants to come work for me full time this summer. He doesn't want any pay-just wants to associate with the great man." MJ said "Sounds like a weirdo to me". "Not at all," Skinner replied, "I talked with him a little yesterday. He seemed very bright." "What made you think so?" she asked. "He quoted me a lot."

He had great faith in the power of positive consequences, so much so that he completely eschewed the use of punishment. He never punished either of his daught- 
ers, and sometimes went to extraordinary lengths to use only positive consequences in his own life. It was once reported that a young man made a habit of entering Skinner's office without knocking or otherwise announcing himself. This happened every day for about four months. Finally, one day he knocked loudly on Skinner's door and said "Good morning, I thought I would let you know I was here today." Skinner swung around in his chair and said cheerfully "Oh hello! and thanks for knocking. I like it when people do that."

At the age of 86 his body was wearing out. He occasionally apologized for repeating himself in lectures and papers, pointing out that Jorge Luis Borges had once said, "What can I do at 71 except plagiarize myself!" But he always had something new to say. He faced his own death as "a necessary end" without particular fear. In 1983 he wrote (with M. E. Vaughan) Enjoy Old Age to tell others how he continued to be productive and innovative after retirement. The book was written in everyday English, avoiding behavioural jargon, and was published in large print-after all, many of the readers would have failing eyesight. Typically the book was about arranging environmental contingencies-it was subtitled $A$ Programme of Self Management. Its aim was to help old people to behave with tranquillity, wisdom, freedom, dignity, and a sense of humour. For those worried that, by following the script, they wouldn't be given personal credit, he said "You need not worry. Audiences always hiss the villain and cheer the hero. You will be admired for your performance no matter how favourable the circumstances under which you give it. Admiration is one of the ways in which society encourages great performances, and it will go on applauding even if the part is so good that it is always beautifully played. And if you yourself have constructed the world that permits you to live a tranquil, dignified, and enjoyable life, you will be doubly admired-not only for a great performance, but for writing a last act that plays so well."

Frazier, in Walden Two, once said "When I die I shall cease to exist-in every sense of the word. A few memories will soon follow me into the crematorium, and there will be no other record left. As a personal figure, I shall be as unidentifiable as my ashes. That's absolutely essential to the success of all the Waldens." Perhaps so. Science has lost a great man, but his contribution is irreversible.

\section{Carol Cole adds:}

Some two months before his death, I had the privilege of meeting B. F. Skinner in his home at Harvard. I was on a study tour of the States and wrote ahead asking if I might visit him, unaware that he was dying of leukaemia. At the time it seemed to me, a long-time admirer, to be an obvious thing to do, and the fulfilment of an ambition. When I told friends and colleagues of the forthcoming meeting, they expressed surprise. "How on earth did you manage to fix that up?"- "I just wrote and asked him."

It was a mark of the man that even in the last few months of his life, when every social contact increased the probability of infection, he continued to make time for professional meetings, even with decidedly obscure visitors from "across the pond". 
We met in his basement study cum den in a quiet leafy neighbourhood of Harvard on a glorious sunny afternoon. He was relaxing in an old and clearly much loved leather reclining chair. He said then, prophetically but calmly, that he "did not expect to see out the end of the year". Knowing this made our discussion all the more precious and with hindsight much more poignant.

To paraphrase Lewis Carroll, we spoke of many things. About the importance of education, his great love; about his concern for world peace and east-west detente; and the enormous potential of a radical behaviourist approach if applied constructively to social issues. He took great delight in recounting how he had once been challenged by a newspaper reporter to put theory into practice by training a dog he had never seen. In an ingenious experiment using the photographer's flash gun, in some hotel bedroom hired by the newspaper, he readily taught the animal to jump up against a series of heights marked on the wall, and accordingly won his bet.

Another anecdote concerned a luncheon he attended at which Carl Jung was present. Jung had been telling him that his behaviourist ideas were all very well but they only applied to non-humans. Skinner duly sent a note along to the Chairman of the lunch saying "Watch Jung's right hand." He then proceeded to reinforce Jung's arm-waving by discreet noddings of the head. Sure enough, by the end of the meal Jung's right hand was gesticulating wildly, behaviour of which its owner was blissfully unaware. Skinner smugly sent a second note to the Chairman saying "I told you so!" only to receive a reply saying "That's all very well, but now extinguish it!" "For a long time I never told this story", said Skinner, "to save any embarrassment, only to hear that a fellow lunch guest had been dining out on it for years!"

He was a kind, charming and humorous host that afternoon, testimony to the humanity of both his work and the man himself. He has left behind a noble legacy of ideas, which for many of us will continue to be a rich source of inspiration. 